\title{
Fernando de los Ríos, a voice of the exiled Spanish Republican at the University of Puerto Rico
}

\author{
Consuelo Naranjo Orovio ${ }^{1}$ and Miguel Ángel Puig-Samper ${ }^{2}$ \\ ${ }^{1}$ Instituto de Historia, CSIC. Albasanz, 26-28, 28037 Madrid \\ e-mail: chelo.naranjo@cchs.csic.es \\ ORCID iD: http://orcid.org/0000-0002-2737-0509 \\ ${ }^{2}$ Instituto de Historia, CSIC. Albasanz, 26-28, 28037 Madrid \\ e-mail: miguelangel.puig@cchs.csic.es \\ ORCID iD: http://orcid.org/0000-0002-6609-819X
}

Submitted: 3 January 2017. Accepted: 27 February 2017

\begin{abstract}
The host of Spanish Republican intellectuals after the Spanish Civil War was linked to the establishment of scientific networks that had been forged before the exile. These networks provided a platform to the Spanish intellectual exile in many American countries. Puerto Rico was one of them. Its university supported the arrival of Republican professors and scientists, some of whom had already been on the island teaching some courses since 1924. Besides, the University of Puerto Rico invited several exiled professors to temporarily stay as guests. Fernando de los Rios was one of them. He stayed as professor in 1928 and 1944. His personal experience, ideology and conception of History and the past were reflected in the classes Fernando de los Rios gave at the University of Puerto Rico in 1944.
\end{abstract}

KEYWORDS: Fernando de los Ríos; Cultural and scientific relationships; JAE; Cultural networks; Spanish Republican exile; University of Porto Rico; 1920-1940.

Citation / Cómo citar este artículo: Naranjo Orovio, Consuelo and Puig-Samper, Miguel Angel (2018) "Fernando de los Ríos, a voice of the exiled Spanish Republican at the University of Puerto Rico". Culture \& History Digital Journal, 7 (1): e005. https://doi.org/10.3989/chdj.2018.005

RESUMEN: Fernando de los Ríos, una voz del exilio republicano español en la Universidad de Puerto Rico.- La acogida de intelectuales republicanos españoles tras la Guerra Civil española estuvo vinculada a la existencia de redes científicas que se fraguaron en los años previos al exilio. Estas redes sirvieron de plataforma al exilio intelectual español en muchos países americanos. Puerto Rico fue uno de ellos. Su Universidad favoreció la llegada de profesores y científicos republicanos, algunos de los cuales ya habían estado en la isla impartiendo cursos desde 1924. Además de país de refugio, por las aulas de la Universidad de Puerto Rico desfilaron varios profesores exiliados invitados temporalmente. Uno de ellos fue Fernando de los Ríos, profesor en distintos momentos y situaciones, 1928 y 1944, que compartió con otros exiliados el deambular por tierras americanas impartiendo el magisterio. Su experiencia personal, su ideología y su concepción de la Historia y del pasado se reflejan en las clases que Fernando de los Ríos dictó en la Universidad de Puerto Rico en 1944.

PALABRAS CLAVE: Fernando de los Ríos; Relaciones culturales y científicas; JAE; Redes; Exilio republicano español; Universidad de Puerto Rico; 1920-1940.

Copyright: $(2018$ CSIC. This is an open-access article distributed under the terms of the Creative Commons Attribution 4.0 International (CC BY 4.0) License. 


\section{THE UNIVERSITY OF PUERTO RICO: A POINT OF UNION BETWEEN PAN-HISPANISM AND PAN-AMERICANISM}

The understanding between Puerto Rico and Spain in the period of this essay; from the 1920s to the 1940s, from an ideological standpoint and similar objectives made it possible to launch an ambitious cultural university project on both sides of the Atlantic. Despite the two countries different political contexts, the cultural projects which were initiated independently and driven by different interests, converged at common points where relations between the former colony and the former metropolis were woven. Only twenty years had passed since 1898 when solid ties started to be established that were grounded in history, language and shared culture. Without knowing the origins of how this interesting cultural project and collaboration was hatched we cannot understand how the exiled Spanish Republicans were received, especially the professors who had created academic networks between Spain and Puerto Rico in the years leading up to 1936, which became a platform for the exiles. On the other hand, to understand the scope and dimensions of this project it is necessary to first look at the history of Puerto Rico and at some of the figures of the young University of Río Piedras, founded in 1903, such as the rector Thomas Benner and Professor Federico de Onís.

The desire to create institutions that offered individuals the possibility to be educated and face the future in another way, in a world where progress was goal; was shared by intellectuals, educators, scientists and some government members in Spain and in Puerto Rico. In the new Century in Spain, politicians and intellectuals driven by Regenerationist ideals looked for causes that impeded social progress and kept the country anchored in secular backwardness. The way out was found by creating schools and institutions to drive education and research. Alongside this, it was necessary to be in contact with other countries where science was further advanced. It was necessary to learn, travel and study abroad, so scholarships were set up benefitting many students and professors. Spain was Europeanised, making knowledge more internationalised, the Government wagering on the idea of learning from others set up the Board for Extension of Studies and Scientific Research (JAE), run by the eminent figure of Santiago Ramón y Cajal in 1907. In a few years, JAE had established a network of centres and laboratories for the most prestigious Spanish intellectuals and scientists of the time. The Centre for Historical Studies, founded by Ramón Menéndez Pidal in 1910, was the centre in charge of studying the history of Spain. He was entrusted with the task of creating points of union with American countries by sending professors, students, and books, etc. (Formentín Ibáñez and Villegas Sanz, 1992; Sánchez Ron, 1988; Ortiz, 1988; López Sánchez, 2006; Puig-Samper, 2007; Naranjo Orovio, 2007; Bernabéu Albert and Naranjo Orovio, 2008). It was a very ambitious project, barely covered by the media and very few individuals, and was only possible by collaborating with the
American countries. The trips were in both directions, and these relationships must be seen and analyzed in this sense as they began with new content and new objectives. Although some voices remembering the old imperial dreams could still be heard, the exchanges were based on new paradigms of understanding and equality. The cultural ties involved the desire to research common projects and were made by slowly managing and weaving very fruitful relations between Spain and Puerto Rico.

In Puerto Rico, defending the increasing Spanish presence in the Puerto Rican University happened at a time which coincided with the political project, the proindependence aspirations, and the social and economic reality marked by an acute crisis leading to conflicts and working-class struggles. The internal political context; the Nationalist party and the Liberal Party were calling for national independence, increased people's aspirations to maintain their signs of identity. The University was a stage and platform of political debate, and it generated an intellectual movement which reflected on the economic, cultural and social problems of the island, marked by the idea of "orphans", as Antonio Pedreira stated, they were members of a generation "whipped between an end and a beginning". Identity was their main discussion topic in a climate where the presence of the United States, cultural absorption, the fate of the country and Puerto Rico's status were discussed. In this environment, recognising Spanish traditions took force as one of the main bases of the Puerto Rican identity and, particularly, defending Spanish as the official language. Therefore, the 30s Generation writers looked to history for new interpretations of the past. The fear of being assimilated and absorbed by North America resulted in history becoming an instrument for fighting from the present and claiming the specificity of the Puerto Rican people, while the intellectual and political elite imagined Spain as a bridge to Europe and a connection with Western civilization. Knowledge and rapprochement with Spain would not only provide them with a knowledge of themselves-"to know Spain is to know ourselves," written in 1930s, but also knowing Spain under another hypothesis was the most effective way to penetrate and understand the European soul. In 1930, in an article entitled "The need for Spanish professors in our University," Filiberto Vázquez said “... Because of Spain we are bathing in full Western civilization so, with her and for ourselves, we must save and preserve our civilization, language, culture and good taste" (Vázquez, 1930: 5 and 8). Despite the project's acceptance, there was also some criticism from those who thought that Spain continued to be scientifically and culturally a backward country (Collado Martell, 1925).

Within this group, the 30s generation came up with the idea of rescuing and reclaiming Hispanic culture (language, history, literature) and helped cement the Puerto Rican identity and the cultural nation. Rapprochement with Spain was proposed from different angles, the University being one of the fundamental pillars to carry it out. Throughout this process, it is interesting to study how the University engaged a mechanism which integrat- 
ed all parties: Puerto Rico, Spain and United States, as well as key people for achieving it: Thomas E. Benner, the University rector and Federico de Onís. Revealing the atmosphere conducive to understanding, as well as for establishing a partnership based on the culture of the three countries, are the words of Thomas Benner who on being named rector signalled that achieving Pan American understanding and dialogue between the Anglo and Spanish cultures was to be one of the University's objectives. In this same vein, the article by William R. Shepherd entitled "Towards a triangular friendship" (1928) must also be remembered. A history professor at Columbia University, Shepherd stressed the value of culture as the most effective means to meet the 'other' and promote rapprochement of peoples. He encouraged the citizens of the United States, Latin America and Spain to contribute to the new cultural and spiritual enterprise whose programme was summarized in 14 points, highlighted as: promote the teaching of Spanish in United States; in Spanish-speaking countries promote the teaching of English; support the reciprocal systematic study of Hispanic and American geography, history and institutions; promote the exchange of professors and students; stimulate American interest in Spain and Latin America, and vice versa, and bring about a shift away from biased views about "others" that similarly existed in North American, Latin American and Spanish societies.

However, the chance of the moment; meaning the existence of conditions that allowed new relations to start up between Puerto Rico and Spain in the intellectual field, wasn't enough to understand why they emerged and, above all, how they were established. While the institutions driving them had an important role, it was the people who worked in them striving to transform the culture loop into a collaboration that lasted several years, and contributing to another way of looking. Puerto Rico and Spain faced the Twentieth Century under other paradigms where culture and science took precedence, overcoming some of the barriers encountered by the old colonial relationship. The new times spoke of an opportunity to get closer under other paradigms, to look and understand with other lenses. Although the project was very focused on the intellectual elite, the cultural exchanges without a doubt accounted for rapprochement. The importance of these relationships transcended the moment as in a few years the foundations of a partnership between the University of Puerto Rico and the Centre for Historical Studies in Madrid were laid, being present at the Puerto Rican University since 1924, when the Centre was visited by young Puerto Rican professors, such as Margot Arce or Antonio Pedreira who did their studies and dissertations there. In the centre of the collaboration between the University of Puerto Rico, Columbia University and the Centre for Historical Studies in Madrid was the key figure of Federico de Onís, always supported by the UPR's rector, Thomas E. Benner. Onís found a great partner in the Rector, who understood that culture could be the vector of the triangle formed by Spain, United States and Puerto Rico (Naranjo Orovio, Luque and Puig-Samper, 2003).
Some brief notes on the life of Federico de Onís will help us to understand the work undertaken by the United States and Puerto Rico which always used the Centre for Historical Studies (CHS) and the Students' Residence, both in Madrid as a reference point and intellectual counterpart. A student of Unamuno, Salamanca his hometown (1885) he moved to Madrid in 1905 to do this PhD under Ramón Menéndez Pidal. Those years were decisive in Onis's career both for the training he received and for the friends and colleagues he met in the Centre for Historical Studies, which he joined from its inception in 1910 in the Origin of the Spanish Language section run by Ramón Menéndez Pidal with Américo Castro, Tomás Navarro Tomás, Julián Paz, Antonio Solalinde, Justo Gomez Ocerin, and others. When Menéndez Pidal took a trip to America in 1915, Onís substituted for him running the Origins of the Spanish Language section (centenary of Federico de Onís 1985). This Centre edited the Revista de Filología Española, the Hispanic Studies Journal was based on this model when the Department of Hispanic Studies at the University of Puerto Rico started it in 1928, counting Fernando de los Ríos among its editors.

In 1915 Onís won the Chair at the University of Salamanca, a position he never held since he left for the United States in 1916. In 1916, he was sent by JAE to Columbia University as they needed a professor to run and organize Spanish language, literature and civilization courses in the Department of Romance languages. Taking advantage of his position, JAE commissioned him to assess the areas where Spain and the United States could collaborate, especially areas related to teaching and promoting Spanish. His trip became definitive after requesting an extension in 1917 and a leave of absence a few years later (1921).

From the United States and Puerto Rico, Onís put together the studies to be done in the Centre for Historical Studies in Madrid, where Spanish studies and history were pivotal axes in the search for the roots of Spanish identity, a programme providing arguments for a broader political project. His time at the Centre for Historical Studies made a mark on Onís's career path, where intellectual work interlinked with cultural projects. He excelled at it, on the one hand, the pursuit of "the national" and defining Spanish culture, on the other hand the challenge to increase the presence of Spain in the Americas. In correspondence between Federico Onís and Américo Castro we find similar interests relating to the need to promote Spanish culture, in part as a way of counteracting the Anglo-Saxon advance. In a letter that Castro wrote to Federico de Onís in May 1928, regarding the Hispanic Studies Journal's objectives he had begun editing at the beginning of the year, he comments:

At each location, it is necessary to do something different: some things in Spain, others in Latin America, and others in the United States. The latter is an area that would be suicidal to abandon. Does anybody believe that if we do not work with the Americans, they will sit still? They would continue doing theirs without us, as 
they already do. The influence that we have managed to exert channelling the Hispanic-North-American activities favourably to our interests, will always be a great advantage for us. If the French, Italians, English or Germans achieved what we have managed to do with the new magazine, having an American style managing procedure for the work done, they would consider themselves very happy; because they spare no means to promote their own culture in the United States.

Supported by the Rector of the University of Puerto Rico and with the support of the Columbia University authorities and Ramón Menéndez Pidal from the Centre for Historical Studies, Federico de Onís spread his nets from his Department at the University of Columbia to Puerto Rico with the teaching programme that the University had at the Río Piedras campus. This programme had had a Summer School of Spanish at the University of Puerto Rico since 1922. In 1924, Onís as director of the Summer School in Spanish, and the rector of the University asked JAE to send Spanish professors. The first was Tomás Navarro Tomás. Initially the collaboration focused on the Spanish professors' trip to the Puerto Rican University as professors on the summer courses that the University offered from 1924 onwards. The level achieved in the summer courses which had prestigious North-American, Puerto Rican and Spanish academics-Tomás Navarro Tomás, 1925 and 1926, Federico Onís, Josephine Holt from the University of Richmond, and José Robles Pazos, Professor of Spanish at the John Hopkins University-was reason enough for Thomas E. Benner to support Federico de Onís' new proposal to him in 1926 to reorganize the Department of Spanish and transform it into the Department of Hispanic Studies. ${ }^{2}$ From then on, Onís became a constant traveller between New York and Puerto Rico where he remained from 1954, after retiring from Columbia University, until his death in 1966. The collaboration soon bore fruit which Thomas E. Benner alluded to in his letter he sent to the Chairman of the Board of Cultural Affairs in the Spanish Ministry of State, on September 5, 1928 (Benner, 1965: 67-111). ${ }^{3}$

Although setting up this project was very important for the University and Spanish studies, it became even more important if we consider the intellectual networks the Puerto Rican and Spanish professors were weaving to the rhythm of philological studies, and attended by a significant number of prestigious intellectuals, including Fernando de los Ríos (Cámara Villar, 2000).

The network was extended to other disciplines especially when the Spanish Civil War began. It was then that Federico de Onís' former colleagues at the Centre for Historical Studies, and colleagues from different areas, in search of a destination, sought his help. Contacts prior to the war and shared intellectual experiences forged friendships and served as the way to admit Spanish Republican exiles to the island. It was no longer only hispanists, linguists and writers, from 1936 onwards, the University of Puerto Rico opened its doors to scientists and intellectuals of different disciplines: mathematicians, lawyers, his- torians, artists, humanists, writers, doctors, philosophers, biologists and so on. It was here where Federico de Onís's great work resided, building a bridge between various cultures, establishing academic collaboration ties which exceeded the circumstances, times, and institutions, managing to perpetuate the spirit that drove the initiative: promoting cultural exchanges and dialogue that would make it possible to advance humanities and sciences.

The work and life of a character who had been part of it since the project's inception will show the reader the everyday reality and the minutia of the collaboration between the University of Puerto Rico, the Centre for Historical Studies in Madrid and North American hispanists. On the following pages, we deal with this from Fernando de los Ríos's presence in the university classrooms of Puerto Rico.

\section{FERNANDO DE LOS RÍOS; PROFILE OF A COMMITTED INTELLECTUAL}

We find Fernando de los Ríos Urruti, University professor, giving lectures at the University of Puerto Rico during the summer at various times between 1928 and 1944. He was not simply a guest professor teaching courses in the summer time in the wonderful Río Piedras campus. He was quite a character within the exiled Spanish intellectual community after the disastrous Spanish Civil War, bringing together the best of the Free Education Institution traditions and democratic socialism in a very personal and most politically humanist and liberal trend.

He was born in Ronda in 1879, the same year as the Spanish Socialist Workers Party (PSOE), to a well-to-do family. As Patricia Barbadillo reminds us (Barbadillo Griñán, 1999), being very young he came to the attention of the famous anarchist Fermín Salvochea in Cádiz, the first person he heard talking of the awakening of the proletarian consciousness, which was permanently etched in his memory. After studying secondary education in Córdoba, he went to Madrid to study law and philosophy, on the advice of his relative Francisco Giner de los Ríos, the soul of the Free Education Institution, who would leave an indelible imprint on Fernando de los Ríos' mind. This family would soon be indispensable in his life, as he moved to Barcelona to occupy a place in Tabacalera, with the help of Hermenegildo Giner de los Ríos and soon he meet his future wife, Gloria Giner, the daughter of his mentor (Ruiz Manjón, 2007; Muñoz-Rojas, 2009; Zapatero, 1999).

After his time in Barcelona, Fernando de los Ríos moved to Madrid to prepare his doctoral thesis, about Plato nothing less, and quickly contacted the Board for Extension of Studies and Scientific Research. This relationship allowed him to gain a scholarship to go to Germany to study in 1909, first in Jena with the professors Rein, Eucken, Thon and Castiglieri and then in Marburg with Professor Natorp. In Germany, he discovered the socialism he would later practice, one that combined humanism with political liberalism, with a neoKantian philosophical basis. ${ }^{4}$ 
Two years later, we find he had become a flamboyant new Professor of Political Law at Granada University, a member of the most important social circles and shortly after, in 1919, a PSOE candidate in the elections, after a period linked to the most reformist groups. An important moment in his biography was his trip to Soviet Russia in 1920 with Manuel Anguiano to study the possible membership of the PSOE in the III International, something that did not occur under the express advice of Fernando de los Ríos, who came to personally know Kropotkin, Lenin, Trotsky and Bukharin. It was a unique experience that he masterfully narrated in his book Journey to Soviet Russia, where he began his analysis with a major statement of intent:

Ni por un instante, al meditar sobre Rusia y pensar en redactar este trabajo, me he sentido hombre de partido, si bien he tenido de continuo la sensación aguda de mi ideal socialista: y es que siempre he considerado a los partidos como órganos de interpretación de los ideales, no como al ideal mismo, y necesitados, por tanto, de vivir en una perenne subordinación a éstos. El ideal es de suyo infinitamente rico, vario, complejo, y el riesgo de todo partido, como el de las Iglesias, reside en el anquilosamiento por dogmatismo. Un partido no debe ser sino una dirección ideal, y porque así lo piensa quien esto escribe y el norte de la suya fue una concepción humanista de la Historia, es por lo que, de razonamiento en razonamiento, llegó a la conclusión, por la vía de la Ética, de que el Socialismo era un imperativo moral que arrancaba de la entraña del problema del hombre. Así me he situado para juzgar el hecho ruso.

Taking the pulse of life conditions in the new Russia and the orientation that followed the revolution, Fernando de los Ríos declared in his work how he had worked to produce his report and had come to some courageous conclusions for his party to take the position: "Sin testigos oficiales, he tenido ocasión de hablar con personas de las más diversas tendencias y ocupaciones: poetas, ingenieros, filósofos, pintores, médicos, abogados, empleados, obreros de diversas industrias, antiguos patronos, socialistas de diversas tendencias, sindicalistas, anarquistas y comunistas militantes".

Likewise, his interview with Lenin, the top leader of the Russian Revolution, is also very instructive:

Henos aquí ante Lenin -en su cuarto de trabajo, tantas veces descrito, amueblado con sobriedad. Una gran carta mural de Rusia atrae de continuo el pensamiento y la mirada de Lenin [...]. El Poder ha suavizado, sin duda, el carácter de Lenin; en el curso de la conversación extensa que hemos tenido, no obstante conocer perfectamente nuestra concepción teórica y táctica, no nos ha dirigido ni una pregunta cuya respuesta pudiera sernos embarazosa, ni una frase veladamente molesta; sin embargo, este hombre ha sido y es temible por el vigor sarcástico de sus sonrisas y sus frases agresivas, mortificantes, incisivas. El blanco de ellas es singularmente el adversario próximo, el llamado reformista. Lenin viste un modesto traje de americana oscuro; nos invita a tomar asiento en una butaca y él lo hace en una silla; inclinado hacia adelante, nos pregunta por España.

Without going much more in-depth in this interesting text of Fernando de los Ríos, it is necessary to comment how the fundamental fact of his interview with Lenin, which without a doubt resulted in the PSOE separating from the III International, was the Spanish professor's question about when freedom would be recovered after the transitional period after the revolution, something that was answered by Lenin in a devastating response: freedom, what for? The response confirmed the thesis of indefinitely retaining the dictatorship of the proletariat to ensure the revolution's achievements, something unacceptable to democratic socialism. For Fernando de los Ríos, the idea of freedom was essential to mankind's progress via socialism and in the conclusions of his work he notes so convincingly:

And as anticipating what would happen later, the professor pondered: "Will Russia reach the understanding that equality can only be sought by freedom? If not so, there would be two languages in socialism", but he was always optimistic in his assessments and reached the definitive conclusion at the end of his analysis of the Russian Revolution in his work:

\begin{abstract}
...el mundo tenderá civilmente su alma con anhelo hacia el principio eterno que Kant llamara "el hombre como fin en sí"; recogerá "La declaración de derechos del trabajador" con igual amor que la que afirma "los del hombre", y en su virtud se orientará en un socialismo que corresponda a su interna finalidad: la comunidad de hombres libres en una sociedad económicamente disciplinada.
\end{abstract}

Three years later we find Fernando de los Ríos as Madrid Court Deputy, specially commissioned to investigate the Annual disaster in the context of the disastrous Spanish colonial policy, something that would be quickly cut short by General Miguel Primo de Rivera's military coup on September 13, 1923. He had belonged to the Freemasons; a member of the Alhambra Lodge in Granada, in the Great Spanish Orient since 1926. His activities regarding this were reflected in the fascist tribunal's judgment, which was set up under the name of the Court of Repression of Masonry and Communism, its ruling explained:

Resultando que el procesado rebelde Fernando de los Ríos Urruti, ingresó en la Masonería, en la logia "Alhambra" de Granada, adoptando el nombre simbólico de "Jugan" y alcanzó el grado tercero de "Maestro Masón". En el año mil novecientos veintisiete representó ante la VI Asamblea Nacional Simbólica celebrada en Madrid a la "Logia Regional del Mediodía de España", y en mil novecientos veintiocho, también representó a la citada logia en la VII Asamblea Nacional Simbólica, celebrada en Gijón. En mil novecientos treinta y uno asistió en Madrid como Vocal Primero a la $\mathrm{X}^{\mathrm{a}}$ Asamblea Nacional Simbólica de la Gran Logia Española. Su actuación masónica fue muy intensa y mereció elogios de la Secta, que encomiaba sus labores desarrolladas en favor de los 
"sefarditas" y en pro de una enseñanza y profesorado laicos (Peláez y Serrano Alcaide, 1995, Tomo II: 143144).

Fernando de los Ríos's critical position with the dictatorship, contrasting with that of other intellectuals and politicians, came to a peak when, in protest of university policy, he resigned his chair in 1929, along with Ortega y Gasset, Jiménez de Asúa, Sánchez Román and Garcia Valdecasas. Two years later, he was prosecuted and imprisoned for his Revolutionary Committee membership which aimed to proclaim a Republic, when he was freed he stood at the April 12 municipal elections.

The Republic was proclaimed, Fernando de los Ríos was appointed Minister of Justice in Alcalá Zamora's Government, he promoted the divorce law and the jury act among others, and penitentiary system reform by appointing Victoria Kent as Director-General of prisons. Now with Azaña's Government, Fernando de los Ríos took the position of Public and Fine Arts Instruction, where he carried out some notable tasks such as founding the Menéndez Pelayo University, creating the Pedagogical Missions and especially 10,000 schools in the Spanish territory, something which showed his institutional obsession with education as a means of achieving a prosperous future and a secular perspective. After a brief stint in the Ministry of State, he had to admit defeat in the November 1933 elections, something that deeply troubled him up to the 1936 elections which he actively participated in from the Granada candidacy. Shortly after briefly serving as Rector of the Central University and he became Ambassador of Spain in Washington on October 20, 1936, where he stayed until March 1939, experiencing the Spanish tragedy from the United States. Shortly after returning to academic activity thanks to his Political Law and Political History of Latin America and Spain chair at the New School for Social Research in New York, which also allowed him to make trips throughout Latin America as a lecturer.

As a professor, and from his management positions, Fernando de los Ríos collaborated and cooperated with the enterprise he set up in the University of Puerto Rico and the University of Columbia. De los Ríos took any opportunity to support Onis, whom he considered a propagator of Spanish culture. He commented on how important his work was in an article published in El Imparcial in 1928, "Federico de Onís judged by Fernando de los Ríos", when Onis gave a conference in the Puerto Rican Athenaeum, titled "The current value of Spain" (De los Ríos, 1928).

Fernando de los Ríos started participating in JAE's cultural enterprise launched by different American universities-1926 in Mexico, 1927 in Cuba and later in Puerto Rico. This was because of his involvement in JAE and later as the Republican Minister of State. During his term, he agreed to promote the exchange of professors, sponsor pre-Columbian antiquities studies, and publish a Latin American magazine, as well as pass out the best Spanish school texts to the outlying republics and have a contest to write a book of Latin American history. Part of this rapprochement policy was approved on June 30, 1933, as the Hispanic American Cultural Plan, with Minister Fernando de los Ríos being present.

As Virgilio Zapatero (1999) reminds us, in June 1940, he returned to the University of Morelia, where he had been doctor honoris causa since 1926, to give a course on "Modern humanist socialism", in a country he had been fascinating in since his first trip for the Hispanic-Mexican Institute inauguration, accompanied by the physicist Blas Cabrera. Shortly after, he returned briefly to the United States to give courses at the Universities of Berkeley and Columbia. But he really was more interested in the Latin American world, above all in developing an old intellectual project about America's Hispanic roots. He oriented his following work trips to this starting with Cuba. In mid-August 1941, he went to the Shawne in Havana, where he had been invited to participate on the University's summer course, as well as giving other courses organized by the Spanish Republican Circle and was even feted by President Batista. It should be remembered that he was well known in Cuba after his trip in 1927, Blas Cabrera also, for giving lectures at the Hispanic-Cuban Culture Institution set up by Fernando Ortiz, as well as at the University of Havana and in Matanzas (Naranjo Orovio and Puig-Samper, 2005).

On his way to Colombia for this new intellectual itinerary, the National University invited him to give two lectures in Panama. On September 17, he was received at Bogota airport by the rector Nieto Caballero and Daniel Samper, Dean of the Law and Political Science Faculty. Shortly afterwards he would be with Spanish colleagues of the likes of José Prat, Josep Cuatrecasas, Luis Zulueta, Ots Capdequí, etc., who he shared the experiences of exile with, and lectured at the University of Bogota and the Spanish Republican Atenaeum. The next stop in this tireless journey was Ecuador, where he arrived in early October that year, giving a lecture on the 15 th at the Teatro Nacional Sucre. During his visit to Guayaquil, he recalled the poet Federico García Lorca and his work; a man always in his memory, concluding that his own country had killed him. Finally, the Central University named him doctor honoris causa on the $23 \mathrm{rd}$, when he spoke about the "echoes of the crisis of culture" in educational systems. After a brief stint in Peru, Professor Fernando de los Ríos arrived in Bolivia, especially visiting Sucre where he wanted to consult the archives for the work he was preparing, as well as La Paz, Potosi and Cochabamba. At the beginning of December, he was in Chile which coincided with the United States entering World War II after the Japanese air attack on Pearl Harbour, which although on one hand was dramatic, on the other it opened the door for hope among exiled Spaniards, as De los Rios himself explained in his Chilean lectures, he considered the possible Allied victory could end the Franco regime. A hope he repeated during his visit to Córdoba and Buenos Aires in Argentina in January 1942, although he was always reluctant to make political statements, as he considered his trip to be strictly academic. After a week in Montevideo, 
where he was also honoured by the academic authorities, his journey continued heading to Rio de Janeiro and then the last stop in Puerto Rico.

\section{FERNANDO DE LOS RÍOS AT THE UNIVERSITY OF PUERTO RICO}

On Don Fernando's first visit to Puerto Rico at the end of May 1928, he came from New York, where he had been a visiting professor at Columbia University since earlier that year. This time the University of Puerto Rico asked him to start the academic year at the Río Piedras and Mayagüez campuses. A busy schedule awaited on the island, where he stayed until June 4. Two days after the Conference given at the University on May 23, he gave another at the Puerto Rico Athaeum titled "the three drivers of current Spanish ideology: Giner, Unamuno and José Ortega y Gasset".

In 1929 Fernando de los Ríos returned to Puerto Rico under the auspices of the Puerto Rican Spanish Cultural Foundation, to teach one of the summer courses at Rio Piedras, whose collaboration programme with Spain had been set up by Federico de Onís and the University's Rector. As well as the summer school professors, and academic course professors, this programme had other professors such as Tomás Navarro Tomás, in 1925, 1926 and 1928; Américo Castro Quesada, in 1928; Angel Valbuena Prat, who was a professor during the 1928-1929 academic year; Samuel Gili Gaya, for 1929-1930; Manuel García Blanco, 19311932; Gabriela Mistral, 1932-1933, and Jose A. Balseiro who remained at the University from 1933 to 1936.

As Spanish Ambassador to the United States during the second Republic, he maintained close relationships with Puerto Rico and Federico de Onís, whom he supported in promoting Spanish culture in the United States, particularly in New York through the Institute of Spain. After 1936, the Spanish Republican exodus began and Puerto Rico received a group of outstanding professionals from different knowledge areas. The island became a permanent or semi-permanent refuge place for many professors, such as Sebastián González García, Alfredo Jimeno Matilla and family, Rafael Troyano de los Ríos, Angel Botello Barros, Carlos Marichal, Jose Vela Zanetti, Segundo Serrano Poncela, Víctor Cuquerella, Francisco Vázquez Díaz (Compostela), Eugenio Granell, Juan Ramón Jiménez, Honorato Estella Entralgo, Pablo Casals, María Rodrigo, Angel V. Rodriguez Olleros, Carlos Gubern Puig, Emilio Morayta Núñez, José Manuel García Madrid, among others (Naranjo Orovio and Puig-Samper, 2009; Naranjo Orovio, Albert Robatto and Luque, 2011). Many professors from other countries passed through the University classrooms hired for specific activities, as well as others who used Puerto Rico as a means of entering the United States. This is the case of Fernando de los Ríos, María Zambrano, Vicente Lloréns Castillo, Francisco Ayala, José Medina Echeverría, Américo Castro, Javier Malagón, Cipriano Rivas Cherif, Alfonso Rodríguez Aldave, José María Ots Captequí, Claudio Sánchez Albornoz, Jorge Guillén, and many others.
As Spanish Republican Ambassador in Washington and a member of the New School for Social Research, the University of Puerto Rico invited him to visit on several occasions between 1941 and 1944. On the island, he participated in different pro-Spanish Republic events organized by the Pro-Democratic Spain Association, and collaborated in cultural missions set up by the University across the country. Likewise, it must be noted that the rector Jaime Benítez appointed him official representative of the University of Puerto Rico in the First Spanish Exiled Professors Meeting, held at the University of Havana in 1943 (Naranjo Orovio, 1988). ${ }^{5}$ His visits to Puerto Rico occurred in 1939, 1942 and 1944.

On this 1924 trip, he was suggested for the rector position at the University of Puerto Rico after Dr. Rexford G. Tugwell resigned, according to information from the El Mundo newspaper published on 24th February, with the support of the students and many of Fernando de los Ríos' professor disciples. His name had already been considered as possible rector a few years earlier, after the triumph of the Popular Democratic Party. However, the reality was that on the 12th September that year another character essential to the Puerto Rican University and the Spanish exiles would be appointed to the post: Jaime Benítez.

Always with the hope of restoring democracy in Spain, Fernando de los Ríos accepted the Spanish Government in exile's Minister of State post, shortly after the exiled Spanish professors meeting in Havana, so he temporarily moved to Paris. After the end of World War II, disappointed by the indifference of the European powers and the United States towards the Franco dictatorship, being more concerned about the Communist threat, Fernando de los Ríos fell into depression and become ill which led to his death in May 1949 at his North American home.

\section{BY WAY OF CONCLUSION}

There is a lot of evidence of his tenure at the University of Puerto Rico, especially significant during his 1943 visit were his conferences on the history of Europe, mainly, and on the United States and Latin America. In his lectures, culture was the leading thread of history, which he masterfully wove with political, scientific and philosophical issues. On June $16^{\text {th }}$, under the generic title "Evolution and the crisis of modern culture since the industrial revolution", Fernando de los Ríos began the course by warning students that classes would be dialogic and Socratic, as he had learned from his uncle Francisco Giner de los Ríos, even leaving a full day for the students to question him. The concept of history and its morphology, the crises throughout time and explanations of concepts and institutions such as tolerance, freedom, democracy or Parliament occupied an important part of his lectures. His lectures were sprinkled with examples taken from different moments in the history of humanity which made this course an exercise in transversal education where he intertwined the history of ideas, philosophy, economic history, cultural history and political history. He set forth the 
power of the idea, and the creative power that this had as the means of achieving. Recalling his student years at the universities of Paris and Jena in the first decade of 1910, he noted, "a process of moral and intellectual seeding, [that] could create a type of society which was different from the totalitarian political society we were living in". Faith in individual regeneration through education and the value of this in individual citizen training remained the professor's ultimate goal, as it was when it was part of the Spanish political education League founded in 1913.

In his farewell to the course, he recommended to those responsible for education that they educate, not just teach; giving thanks for their hospitality he concluded: "que no nos abandone la luz del ideal en el camino de nuestra vida".

\section{ACKNOWLEDGEMENTS}

This study has been done under the research project HAR2015-66152-R, MINECO.

\section{NOTES}

1 Archivo Federico de Onís, Universidad de Puerto Rico, Río Piedras (AFO), Serie Noticias y Actividades. O-NA/C-44.33

2 Archivo Central de la Universidad de Puerto Rico (ACUPR), Fondo Organización y sus Funciones. F.D.O. E-

3 In the letter, Benner acknowledged the education of the magnificent Spanish professors, Federico Onís, Tomás Navarro Tomás, Fernando de los Ríos, and Américo Castro who had taught at the University of Puerto Rico. In response, the Chairman of the Cultural Relations Board sent a letter on November 12 of that year thanking him for his words. Archivo General de la Administración de Alcalá de Henares (AGAAH), Asuntos Exteriores, Sección VIII-Relaciones Culturales, Caja 1282.

4 Residencia de Estudiantes, Madrid. Fondo JAE. Sign. 280790340/ JAE/123/196. Fernando de los Ríos Urruti's record: Board for Extension of Studies. Documentation concerning his pension to study the philosophical currents of pedagogy in Germany, 1908-1911. A request to join the Centre for Historical Studies in Madrid as a student in 1911. Documentation relating to a pension for studying the new orientations of constitutional law for the public service organization, 1914-1922. Correspondence with José Castillejo and documentation on his attending the 6th International Congress of Philosophy at the University of Harvard and his courses in the Hispanic-Mexican Institute of Mexico and the University of Havana, 1926-1930. Autobiographical, notes [s.a.].

5 ACUPR, Expedientes Personales Pasivos, D-36

\section{REFERENCES}

Barbadillo Griñán, Patricia (1999) «Una idea de España». In Fernando de los Ríos 1879-1949. Fundación Fernando de los Ríos, Granada: 77-83.

Benner, Thomas B. (1965) Five Years of Foundation Building. The University of Puerto Rico 1924-1929. University of Puerto Rico, Río Piedras.

Bernabéu Albert, Salvador y Naranjo Orovio, Consuelo (2008) Historia contra la 'desmemoria' y el olvido: el americanismo en el
Centro de Estudios Históricos y la creación de la revista Tierra Firme (1935-1937). Vol. 1. In Tierra Firme edited by Bernabéu Albert, Salvador y Naranjo Orovio, Consuelo. Edición facsimilar de la revista. 7 vols. CSIC-Residencia de Estudiantes-Sociedad Estatal de Conmemoraciones Culturales, Madrid.

Centenario de Federico de Onís (1885-1966) (1985). Río Piedras, Oficina de Publicaciones e Investigaciones, Facultad de $\mathrm{Hu}-$ manidades, Universidad de Puerto Rico.

Collado Martell, Alfredo (1925) «La Doctrina Monroe y el Pan Americanismo». Summer School News, III, 1: 4-6.

Cámara Villar, Gregorio (coord.) (2000) Fernando de los Ríos y su tiempo. Editorial Universitaria, Granada.

Formentín Ibáñez, Justo y Villegas Sanz, M. 'José (1992) Relaciones culturales entre España y América: La Junta para la Ampliación de Estudios. Editorial Mapfre, Madrid.

López Sánchez, José María (2006) Heterodoxos españoles. El Centro de Estudios Históricos, 1910-1936. Marcial Pons-CSIC, Madrid.

Muñoz-Rojas, Ritama (2009) Poco a poco os hablaré de todo: historia del exilio en Nueva York de la familia de los Ríos, Giner, Urruti: cartas 1936-1953. Publicaciones de la Residencia de Estudiantes, Madrid.

Naranjo Orovio, Consuelo (1988) Cuba, otro escenario de lucha. La Guerra Civil y el exilio republicano español. CSIC, Madrid.

Naranjo Orovio, Consuelo (coord.) (2007) La Junta para Ampliación de Estudios y América Latina: memoria, políticas y acción cultural (1907-1939). Monográfico Revista de Indias, 239.

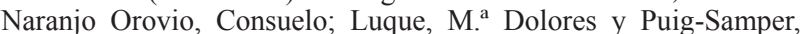
Miguel Ángel (eds.) (2003) Los lazos de la cultura. El Centro de Estudios Históricos de Madrid y la Universidad de Puerto Rico, 1916-1939. CSIC-Universidad de Puerto Rico, Madrid.

Naranjo Orovio, Consuelo y Puig-Samper, Miguel Ángel (2005) «Spanish Intellectuals and Fernando Ortiz (1900-1941)». In Cuban Counterpoints: The Legacy of Fernando Ortiz edited by Font, Mauricio A. and Quiroz, Alfonso W. Lexington Books, New York: 9-37.

Naranjo Orovio, Consuelo y Puig-Samper, Miguel Ángel (2009) «De isla en isla. Los españoles exiliados en Santo Domingo, Puerto Rico y Cuba». Arbor: Los destinos inciertos: el exilio republicano español en América Latina (Monográfico), 735: 87-112.

Naranjo Orovio, Consuelo; Albert Robatto, Matilde y Luque, M. ${ }^{\text {a }}$ Dolores (eds.) (2011) El eterno retorno. Exiliados republicanos españoles en Puerto Rico. Doce Calles, Aranjuez (Madrid).

Ortiz, Eduardo L. (1988) «Las relaciones científicas entre Argentina y España a principios de este siglo. La Junta para Ampliación de Estudios y la Institución Cultural Española». In La Junta para Ampliación de Estudios e Investigaciones Científicas 80 años después (1907-1987), edited by Sánchez Ron, José Manuel, vol. II, CSIC, Madrid: 119-158.

Peláez, Manuel J. y Serrano Alcaide, Concepción (1995) Epistolario selectivo de Fernando de los Ríos Urruti. [s.e.], Barcelona.

Puig-Samper, Miguel Ángel (ed.) (2007) Tiempos de Investigación. $J A E-C S I C$, cien años de ciencia en España. CSIC, Madrid.

Ruiz Manjón, Octavio (2007) Fernando de los Ríos: un intelectual en el PSOE. Síntesis, Madrid.

Sánchez Ron, José Manuel (ed.) (1988) 1907-1987. La Junta para Ampliación de Estudios e Investigaciones Cientificas. 2 vols., CSIC, Madrid.

Shepherd, William R. (1928) «Hacia la amistad triangular». Revista de Estudios Hispánicos, I, 1: 1-17.

Vázquez, Filiberto (1930) «La necesidad de maestros españoles en nuestra Universidad». ABC Universitario, 1, 8: 5 y 8.

Zapatero, Virgilio (1999) Fernando de los Ríos: biografía intelectual. Pre-Textos, Granada. 